Syntax Literate : Jurnal Ilmiah Indonesia p-ISSN: 2541-0849

e-ISSN : 2548-1398

Vol. 4, No. 12 Desember 2019

\title{
ANALISIS MOTIVASI, INDEPENDENSI, OBYEKTIVITAS, INTEGRITAS, KOMPETENSI DAN PENGALAMAN KERJA TERHADAP KUALITAS AUDIT (STUDI KASUS DI LINGKUNGAN INSPEKTORAT SE-KARESIDENAN PEKALONGAN)
}

\section{Bahri Kamal dan Imam Bukhari}

DIII Akuntasi Politeknik Harapan Bersama Tegal

Email: bahrikamal17@gmail.com dan bukhari.imam@yahoo.co.id

\begin{abstract}
Abstrak
Tujuan dari penelitian ini adalah untuk menganalisis pengaruh motivasi, independensi, obyektivitas, integritas, kompetensi dan pengalaman terhadap kualitas audit di lingkungan Inspektorat residensi se Pekalongan. Objek penelitian ini adalah auditor di Inspektorat Lingkungan se Kabupaten Pekalongan. Penelitian ini menggunakan penelitian kuantitatif dengan sampel 93 auditor. Metode analisis yang digunakan dalam penelitian ini adalah regresi linier berganda. Metode pengumpulan data dalam penelitian ini menggunakan kuesioner dengan teknik proporsional random sampling dan rumus Slovin.
\end{abstract}

Kata kunci: Kualitas Audit, Motivasi, Independensi, Objektivitas, Integritas, Kompetensi, Pengalaman

\section{Pendahuluan}

Upaya yang telah dilakukan negara untuk meminimalisir kerugian adalah dengan menerapkan pengawasan keuangan atau juga disebut audit keuangan (Dimyati, 2018). Pengawasan Internal pemerintah adalah salah satu tugas utama manajemen pemerintah sebagai upaya mewujudkan sistem pemerintahan yang baik (good governance) berdaya guna, berhasil guna, bersih dan bertanggung jawab. Sebagaimana diatur dalam Peraturan Menteri Negara Pendayagunaan Aparatur Negara (Indonesia, 2007) Aparat Pengawasan Internal Pemerintah (APIP) merupakan Instansi Pemerintah yang memiliki tugas dan fungsi melakukan pengawasan sebagai berikut:

1. Badan Pengawas Keuangan dan Pembangunan (BPKP) bertanggung jawab kepada Presiden

2. Inspektorat Jenderal bertanggung jawab kepada Menteri

3. Inspektorat Provinsi bertanggung jawab kepada Gubernur

4. Inspektorat Kabupaten/Kota bertanggung jawab kepada Bupati/Walikota. 
Kualitas audit yang dilakukan oleh Inspektorat di Karesidenan Pekalongan sekarang ini sedang menjadi perhatian, karena ada beberapa masalah audit yang tidak ditemukan oleh petugas inspektorat sebagai auditor internal, akan tetapi ditemukan oleh auditor eksternal, yaitu BPK.

Laporan Hasil Pemeriksaan (LHP) atas Laporan Keuangan Pemerintah Daerah (LKPD) yang dilaksanakan oleh BPK tercantum dalam Laporan Hasil Pemeriksaan atas:

1. Kepatuhan terhadap Peraturan Perundang-undangan,

2. Sistem Pengendalian Intern (SPI), dan

3. Laporan Keuangan.

Angka temuan dari hasil pemeriksaan BPK atas LKPD Tahun Anggaran 2013 untuk Kabupaten/Kota di Karesidenan Pekalongan adalah sebagai berikut:

Tabel 1 Jumlah Temuan Kabupaten/Kota di Karesidenan Pekalongan

\begin{tabular}{clc}
\hline No. & Kabupaten/Kota & $\begin{array}{c}\text { Jumlah } \\
\text { Temuan }\end{array}$ \\
\hline 1. & Kabupaten Brebes & 29 \\
\hline 2. & Kota Tegal & 20 \\
\hline 3. & Kabupaten Tegal & 21 \\
\hline 4. & Kabupaten Pemalang & 19 \\
\hline 5. & Kota Pekalongan & 13 \\
\hline 6. & Kabupaten & 30 \\
& Pekalongan & \\
\hline 7. & Kabupaten Batang & 27 \\
\hline
\end{tabular}

Sumber: Ikhtisar Hasil Pemeriksaan Semester I Tahun 2014, BPK-RI

Adanya temuan-temuan BPK yang tertuang dalam LHP tersebut di atas mengindikasikan bahwa kualitas audit petugas Inspektorat di Karesidenan Pekalongan masih relatif rendah.

Pentingnya pemahaman akan audit berkualitas akan mewujudkan pemerintahan daerah yang akuntabel mampu memotivasi auditor untuk memanfaatkan pengalaman, kompetensi, independensi, obyektivitas dan integritas yang dimilikinya. Jadi dengan pertimbangan tersebut di atas, perlu untuk diketahui pengaruh pengalaman kerja, independensi, obyektivitas, integritas, kompetensi dan motivasi terhadap kualitas audit dalam pengawasan yang dilaksanakan oleh Inspektorat di Karesidenan Pekalongan.

Seorang auditor harus memiliki keahlian dan pelatihan teknis yang cukup dalam melakukan audit. Selain itu, auditor juga harus mempunyai pengetahuan mengenai metode dan teknik audit serta mengembangkan pengalamannya dalam bidang 
Analisis Motivasi, Independensi, Obyektivitas, Integritas, Kompetensi Dan Pengalaman

Kerja

pemerintahan seperti organisasi, fungsi, program dan kegiatan pemerintahan (BPKP, 1998).

Pada prinsip-prinsip dasar Standar Audit Intern Indonesia dinyatakan bahwa semua hal yang berhubungan dengan penugasan audit internal, APIP dan kegiatan audit internal harus independen serta auditor harus obyektif dalam pelaksanaan tugasnya. Independensi APIP dan kegiatan audit serta obyektivitas auditor sangat dibutuhkan agar kredibilitas hasil audit semakin baik.

Selain itu, di dalam Kode Etik APIP dalam PERMENPAN No. PER/04/M.PAN/ 03/2008, salah satu tujuannya adalah mencegah terjadinya tingkah laku yang tidak etis, agar terpenuhi prinsip-prinsip kerja yang akuntabel dan terlaksananya pengendalian audit sehingga terwujud auditor yang kredibel dengan kinerja yang optimal dalam pelaksanaan audit. Prinsip-prinsip perilaku yang berlaku bagi auditor antara lain integritas, obyektivitas dan kompetensi. Integritas dibutuhkan agar auditor berlaku jujur dan tegas dalam melaksankan audit, obyektivitas dibutuhkan agar auditor dapat berlaku adil tanpa dipengaruhi oleh pihak-pihak tertentu yang memiliki kepentingan terhadap hasil audit dan kompetensi auditor diukur oleh wawasan dan pengetahuan yang dibutuhkan untuk menjalankan tugas.

Pengalaman, Kompetensi, Independensi, Obyektivitas dan Integritas merupakan standar yang harus dimiliki oleh seorang atau lebih auditor untuk dapat menjalankan audit dengan baik. Namun, auditor yang memiliki kelima hal tersebut di atas belum tentu memiliki komitmen untuk menjalankan audit dengan baik. (Agusti \& Pertiwi, 2013), hanya dengan adanya motivasi, maka seseorang akan memiliki semangat besar untuk mencapai tujuan dan memenuhi kualifikasi yang ditentukan. Jadi motivasi akan mendorong seseorang, dalam hal ini adalah auditor, untuk berprestasi, memiliki inisiatif dan rasa percaya diri yang tinggi.

\section{Metode Penelitian}

Data dalam penelitian ini diperoleh melalui kuesioner, yaitu memberikan beberapa pertanyaan tertulis kepada responden. Nilai jawaban yang diberikan responden akan dihitung menggunakan score dalam skala likert yaitu pertanyaan yang menunjukan bobot jawaban dari responden. Skala ini digunakan untuk mengetahui respon subyek (koresponden) tentang fenomena sosial, dimana respon ini diukur ke dalam 5 poin skala 
Analisis Motivasi, Independensi, Obyektivitas, Integritas, Kompetensi Dan Pengalaman

Kerja

dengan interval yang sama, yaitu 5 kategori sebagai nilai jawaban dan 5 kategori nilai. Nilai yang tertinggi 5 dan nilai yang terendah adalah 1. Skala ini terdiri 5 penilaian, yaitu sangat setuju (score 5), setuju (score 4), netral (score 3), tidak setuju (score 2), dan sangat tidak setuju (score 1).

Kemudian dicari rata-rata dari setiap item jawaban responden, sehingga mempermudah penilaian. Untuk menentukan panjang interval digunakan rumus interval menurut (Agusti \& Pertiwi, 2013) sebagai berikut:

$$
\mathbf{I}=\mathbf{R} / \mathbf{k}
$$

Keterangan:

I = interval

$\mathrm{R}=$ skor tertinggi - skor terendah

$\mathrm{k} \quad=$ jumlah kelas

\section{Hasil dan Pembahasan}

Penelitian dilakukan terhadap 93 auditor di wilayah Karesidenan Pekalongan. Hasil survey menunjukkan bahwa rata-rata auditor berjenis kelamin perempuan, berusia antara 40-50 tahun, masa kerja kurang dari 5 tahun dan sebagian besar memiliki tingkat pendidikan terakhir S1.

Tabel 2 Karakteristik Responden

\begin{tabular}{|c|c|c|}
\hline Karakter & Jumlah & $\%$ \\
\hline \multicolumn{3}{|l|}{ Usia } \\
\hline$<40$ Tahun & 27 & 29 \\
\hline 40 - 50 Tahun & 47 & 51 \\
\hline$>50$ Tahun & 19 & 20 \\
\hline \multicolumn{3}{|l|}{ Jenis Kelamin } \\
\hline Laki-laki & 42 & 45 \\
\hline Perempuan & 51 & 55 \\
\hline \multicolumn{3}{|l|}{ Masa Kerja } \\
\hline$<40$ Tahun & 38 & 41 \\
\hline 40 - 50 Tahun & 30 & 32 \\
\hline > 50 Tahun & 25 & 27 \\
\hline \multicolumn{3}{|l|}{ Pendidikan Terakhir } \\
\hline $\mathrm{S} 1$ & 56 & 60 \\
\hline S2 & 37 & 40 \\
\hline
\end{tabular}


Tabel 3 Nilai Rata-rata (Mean)

\begin{tabular}{|c|c|c|c|}
\hline No. & Variabel & Indikator & Rata-rata \\
\hline 1. & Kualitas Audit (Y) & $\begin{array}{l}\text { Kesuaian audit dengan standar } \\
\text { audit, Kualitas laporan hasil } \\
\text { pemeriksaan }\end{array}$ & 3,98 \\
\hline 2. & Motivasi (X6) & $\begin{array}{l}\text { Urgensi audit yang berkualitas, } \\
\text { Ketangguhan, Keuletan, } \\
\text { Konsistensi }\end{array}$ & 3,28 \\
\hline 3. & Independensi (X2) & $\begin{array}{l}\text { Independensi penyusunan } \\
\text { program, Independensi } \\
\text { pelaksanaan program, } \\
\text { Independensi pelaporan }\end{array}$ & 3,89 \\
\hline 4. & Obyektivitas (X3) & $\begin{array}{l}\text { Bebas dari benturan kepentingan, } \\
\text { Pengungkapan kondisi sesuai fakta }\end{array}$ & 4,07 \\
\hline 5. & Integritas (X4) & $\begin{array}{l}\text { Kejujuran auditor, Keberanian } \\
\text { auditor, Sikap bijaksana auditor, } \\
\text { Tanggung jawab auditor }\end{array}$ & 4,21 \\
\hline 6. & Kompetensi (X5) & $\begin{array}{l}\text { Mutu personal, Pengetahuan } \\
\text { umum, Keahlian khusus }\end{array}$ & 3,76 \\
\hline 7. & Pengalaman Kerja (X1) & $\begin{array}{l}\text { Kecukupan Pengalaman, } \\
\text { Banyaknya Beban Tugas } \\
\text { Pemeriksaan }\end{array}$ & 3,59 \\
\hline
\end{tabular}

Berdasarkan hasil pengujian hipotesis, maka dapat diketahui bahwa dari 6 hipotesis yang diajukan, seluruhnya dapat diterima sehingga diperoleh persamaan regresi $Y=0,174 X 1+0,011 X 2+0,372 X 3+0,443 X 4+0,075 X 5+0,023 X 6$. Adapun hasil pengujian hipotesis penelitian antara lain, yaitu:

\section{a. Uji Hipotesis 1 (H1)}

Dari hasil pengujian didapatkan nilai koefisien variabel motivasi 0,174 dengan nilai signifikansi $0,006<0,05$, maka Ho (hipotesis nol) ditolak dan menerima Ha (alternatif) yaitu motivasi mempunyai pengaruh yang positif dan signifikan terhadap kualitas audit di Lingkungan Inspektorat se-Karesidenan Pekalongan, dengan demikian hipotesis pertama dalam penelitian ini diterima.

\section{b. Uji Hipotesis 2 (H2)}

Dari hasil pengujian didapatkan nilai koefisien variabel independensi sebesar 0,011 dengan nilai signifikansi $0,014<$ dari 0,05, maka Ho (hipotesis nol) ditolak, dan menerima $\mathrm{Ha}$ (hipotesis alternatif) yaitu independensi berpengaruh positif dan signifikan terhadap kualitas audit di Lingkungan Inspektorat se-Karesidenan Pekalongan, dengan demikian hipotesis kedua dalam penelitian ini diterima. 


\section{c. Uji Hipotesis 3 (H3)}

Dari hasil pengujian didapatkan nilai koefisien variabel obyektivitas sebesar 0,372 dengan nilai signifikansi $0,001<$ dari 0,05, maka Ho (hipotesis nol) ditolak, dan menerima Ha (hipotesis alternatif) yaitu obyektivitas berpengaruh positif dan signifikan terhadap kualitas audit di Lingkungan Inspektorat se-Karesidenan Pekalongan, dengan demikian hipotesis ketiga dalam penelitian ini diterima.

\section{d. Uji Hipotesis 4 (H4)}

Dari hasil pengujian didapatkan nilai koefisien variabel integritas sebesar 0,443 dengan nilai signifikansi $0,000<$ dari 0,05 , maka Ho (hipotesis nol) ditolak, dan menerima $\mathrm{Ha}$ (hipotesis alternatif) yaitu integritas berpengaruh positif dan signifikan terhadap kualitas audit di Lingkungan Inspektorat se-Karesidenan Pekalongan, dengan demikian hipotesis keempat dalam penelitian ini diterima.

\section{e. Uji Hipotesis 5 (H5)}

Dari hasil pengujian didapatkan nilai koefisien variabel kompetensi sebesar 0,075 dengan nilai signifikansi $0,018<$ dari 0,05 , maka Ho (hipotesis nol) ditolak, dan menerima Ha (hipotesis alternatif) yaitu kompetensi berpengaruh positif dan signifikan terhadap kualitas audit di Lingkungan Inspektorat se-Karesidenan Pekalongan, dengan demikian hipotesis kelima dalam penelitian ini diterima.

\section{f. Uji Hipotesis 6 (H6)}

Dari hasil pengujian didapatkan nilai koefisien variabel pengalaman kerja sebesar 0,023 dengan nilai signifikansi $0,010<$ dari 0,05, maka Ho (hipotesis nol) ditolak, dan menerima Ha (hipotesis alternatif) yaitu pengalaman kerja berpengaruh positif dan signifikan terhadap kualitas audit di Lingkungan Inspektorat seKaresidenan Pekalongan, dengan demikian hipotesis keenam dalam penelitian ini diterima.

Dari 93 auditor yang terlibat sebagai responden, maka diketahui informasi mengenai pengaruh dari beberapa variabel yaitu motivasi, independensi, obyektivitas, integritas, kompetensi dan pengalaman kerja terhadap kualitas audit di Lingkungan Inspektorat se-Karesidenan Pekalongan.

Berdasarkan uji hipotesis menunjukkan bahwa motivasi, independensi, obyektivitas, integritas, kompetensi dan pengalaman kerja berpengaruh positif terhadap kualitas audit di Lingkungan Inspektorat se-Karesidenan Pekalongan. Pengaruh yang 
Analisis Motivasi, Independensi, Obyektivitas, Integritas, Kompetensi Dan Pengalaman

Kerja

ditimbulkan dari hasil penelitian menunjukkan arah yang positif, yang berarti bahwa motivasi, independensi, obyektivitas, integritas, kompetensi dan pengalaman kerja yang lebih baik akan meningkatkan kualitas audit di Lingkungan Inspektorat se-Karesidenan Pekalongan.

(Elsi, n.d.) mendefinisikan motivasi sebagai keinginan di dalam seorang individu yang mendorong ia untuk bertindak. Sedangkan menurut Panitia Istilah Manajemen Lembaga Pendidikan dan Pembinaan Manajemen, motivasi adalah proses atau faktor yang mendorong orang untuk bertindak atau berperilaku dengan cara tertentu; yang prosesnya mencakup: pengenalan dan penilaian kebutuhan yang belum dipuaskan, penentuan tujuan yang akan memuaskan kebutuhan, dan penentuan tindakan yang diperlukan untuk memuaskan kebutuhan.

Independen artinya tidak mudah dipengaruhi, karena auditor melaksanakan pekerjaannya untuk kepentingan umum. Auditor tidak dibenarkan memihak kepada kepentingan siapapun. Untuk memenuhi pertanggungjawaban profesionalnya, auditor pemerintah harus bersikap independen karena ia melaksanakan pekerjaannya untuk kepentingan umum. Independensi juga berarti adanya kejujuran dalam diri auditor dalam mempertimbangkan fakta dan adanya pertimbangan yang obyektif tidak memihak dalam diri auditor dalam merumuskan dan menyatakan pendapat-nya. Independensi menghindarkan diri dari hubungan yang bisa merusak obyektifitas seorang auditor dalam melakukan jasa atestasi. Menurut (Pusdiklatwas, 2005), auditor yang independen adalah auditor yang tidak memihak dan yang tidak dapat diduga memihak, sehingga tidak merugikan pihak manapun. Sejalan dengan penelitian yang dilakukan oleh (Ayuningtyas \& Pamudji, 2012), hasil penelitian menunjukkan independensi berpengaruh terhadap kualitas audit sedangkan etika dan Time Budget Pressure auditor tidak berpengaruh terhadap kualitas audit.

Obyektivitas mempunyai pengaruh terendah terhadap kualitas audit di Lingkungan Inspektorat se-Karesidenan Pekalongan dibandingkan dengan kelima variabel bebas lainnya. Rendahnya pengaruh obyektivitas dalam penelitian ini disebabkan karena auditor masih belum sepenuhnya bebas dari benturan kepentingan yaitu dalam bertindak adil tanpa dipengaruhi oleh tekanan atau permintaan dan dalam pengungkapan kondisi sesuai fakta yaitu dalam melakukan tindakan atau dalam proses pengambilan keputusan, belum sepenuhnya menggunakan pikiran yang logis. Sesuai 
Analisis Motivasi, Independensi, Obyektivitas, Integritas, Kompetensi Dan Pengalaman

Kerja

dengan penelitian yang dilakukan oleh (Arianti, n.d.), hasil penelitian menunjukan bahwa obyektivitas berpengaruh positif terhadap kualitas audit di Pemerintahan Daerah.

Integritas adalah sikap jujur, berani, bijaksana dan tanggung jawab auditor dalam melaksanakan audit. Integritas merupakan kualitas yang melandasi kepercayaan publik dan merupakan patokan bagi anggota dalam menguji semua keputusannya. Integritas mengharuskan seorang auditor untuk bersikap jujur dan transparan, berani, bijaksana dan bertanggung jawab dalam melaksanakan audit. Keempat unsur itu diperlukan untuk membangun kepercayaan dan memberikan dasar bagi pengambilan keputusan yang andal (Ayuningtyas \& Pamudji, 2012). Kemudian (Yamato, Okimori, Wibowo, Anshori, \& Ogawa, 2006) menyebutkan integritas auditor internal menguatkan kepercayaan dan karenanya menjadi dasar bagi pengandalan atas judgment mereka. Integritas merupakan kualitas yang melandasi kepercayaan publik dan merupakan patokan bagi anggota dalam menguji semua keputusannya. Dengan integritas yang tinggi, maka auditor dapat meningkatkan kualitas hasil pemeriksaannya (Pusdiklatwas, 2005). Serupa dengan penelitian yang dilakukan oleh David, hasil penelitian menunjukan bahwa integritas auditor berpengaruh positif terhadap kualitas audit di Lingkungan Pemerintah Daerah.

Kompetensi auditor adalah kualifikasi yang dibutuhkan oleh auditor untuk melaksanakan audit dengan benar (Rai, 2008 dalam Sukriah, dkk 2009). Dalam melakukan audit, seorang auditor harus memiliki mutu personal yang baik, pengetahuan yang memadai, serta keahlian khusus di bidangnya. Standar umum pertama menyebutkan bahwa audit harus dilaksanakan oleh seorang atau lebih yang memiliki keahlian dan pelatihan teknis yang cukup sebagai auditor kompetensi berkaitan dengan keahlian profesional yang dimiliki oleh auditor sebagai hasil dari pendidikan formal, ujian profesional maupun keikutsertaan dalam pelatihan, seminar, simposium (Suraida, 2005). Adapun secara umum ada 5 (lima) pengetahuan yang harus dimiliki oleh seorang auditor (Kusharyanti, 2003) menjelaskan bahwa pengetahuan terbagi menjadi : (1.) Pengetahuan pengauditan umum, (2.) Pengetahuan area fungsional, (3.) Pengetahuan mengenai isu-isu akuntansi yang paling baru, (4.) Pengetahuan mengenai industri khusus, (5.) Pengetahuan mengenai bisnis umum serta penyelesaian masalah. Sebanding dengan penelitian yang dilakukan oleh (Efendy, 2010), hasil penelitian menunjukkan 
Analisis Motivasi, Independensi, Obyektivitas, Integritas, Kompetensi Dan Pengalaman

Kerja

bahwa kompetensi mempunyai pengaruh yang positif dan signifikan terhadap kualitas audit di Kantor Pengawasan Keuangan Daerah.

Pengalaman adalah cara pembelajaran yang baik bagi auditor internal untuk menjadikan auditor memiliki banyak teknik audit. Semakin banyak pengalaman auditor, maka semakin mahir auditor mengusai bidangnya maupun aktivitas yang diauditnya. Pengalaman membentuk auditor mampu menghadapi dan menyelesaikan hambatan maupun persoalan dalam pelaksanaan tugasnya, serta mampu mengendalikan kecenderungan emosional terhadap pihak yang diperiksa. Selain pengetahuan dan keahlian, pengalaman auditor memberi kontribusi yang relevan dalam meningkatkan kompetensi auditor. Sejalan dengan penelitian yang dilakukan oleh (Bolang, 2013), hasil penelitian menunjukkan bahwa pengalaman berpengaruh posisitif dan signifikan terhadap kualitas audit.

\section{Kesimpulan}

Berdasarkan hasil analisis dan pembahasan yang dilakukan pada bab sebelumnya, maka dapat ditarik beberapa kesimpulan sebagai berikut:

1. Motivasi, Independensi, Obyektivitas, Integritas, Kompetensi dan Pengalaman Kerja berpengaruh positif dan signifikan terhadap Kualitas Audit di Lingkungan Inspektorat se-Karesidenan Pekalongan. Dengan demikian, semakin tinggi Motivasi, Independensi, Obyektivitas, Integritas, Kompetensi dan Pengalaman Kerja seorang auditor, maka semakin meningkat atau semakin baik kualitas hasil pemeriksaan yang dilakukannya.

2. Secara simultan, keenam variabel tersebut berpengaruh terhadap kualitas hasil pemeriksaan dengan kemampuan menjelaskan terhadap variabel dependen sebesar $71,8 \%$. Sedangkan sisanya $28,2 \%$ dipengaruhi oleh variabel lain diluar model.

3. Pengujian hipotesis menggunakan Regresi Linier Berganda menunjukkan bahwa variabel Integritas memiliki pengaruh terkuat terhadap kualitas audit di Lingkungan Inspektorat se-Karesidenan Pekalongan dibandingkan dengan kelima variabel bebas lainnya.

4. Variabel Independensi mempunyai pengaruh terendah terhadap kualitas audit di Lingkungan Inspektorat se-Karesidenan Pekalongan dibandingkan dengan kelima variabel bebas lainnya. 
Analisis Motivasi, Independensi, Obyektivitas, Integritas, Kompetensi Dan Pengalaman

Kerja

\section{BIBLIOGRAFI}

Agusti, R., \& Pertiwi, N. P. (2013). Pengaruh Kompetensi, Independensi dan Profesionalisme Terhadap Kualitas Audit (Studi Empiris Pada Kantor Akuntan Publik Se Sumatera). Jurnal Ekonomi, 21(03).

Arianti, K. P. (n.d.). dkk. 2014."Pengaruh Integritas, Obyektifitas, dan Akuntabilitas Terhadap Kualitas Audit di Pemerintah Daerah Studi Pada Inspektorat Kabupaten Bulelelng." E-Jurnal S1 Ak Universitas Pendidikan Ganesha Jurusan Akuntansi S1. 2 (1).

Ayuningtyas, H. Y., \& Pamudji, S. (2012). Pengaruh Pengalaman Kerja, Independensi, Obyektifitas, Integritas Dan Kompetensi Terhadap Kualitas Hasil Audit (Studi Kasus Pada Auditor Inspektorat Kota/Kabupaten di Jawa Tengah). Fakultas Ekonomika dan Bisnis.

Bolang, M. S. (2013). Pengaruh Kompetensi, Independensi dan Pengalaman terhadap Kualitas Audit Aparat Inspektorat Kota Tomohon dalam Pengawasan Pengelolaan Keuangan Daerah. Riset Akutansi Dan Auditing Magister Akutansi Fakultas Ekonomi Unsrat, 4(Nomor 2 Desember).

Dimyati, A. (2018). Formulasi Hukum Pidana Dalam Menetapkan Kerugian Negara Pada Tindak Pidana Korupsi. Syntax Literate; Jurnal Ilmiah Indonesia, 3(1), 2133.

Efendy, M. T. (2010). Pengaruh Kompetensi, Independensi dan Motivasi terhadap Kualitas Audit Aparat Inspektorat dalam Pengawasan Keuangan Daerah (Studi Empiris pada Pemerintah Kota Gorontalo). Gorontalo.

Elsi, E. (n.d.). Peran Pembina Asrama dalam Memotivasi Belajar pada Siswi SMA di Asrama Putri. Jurnal Pendidikan Dan Pembelajaran, 3(8).

Indonesia, R. (2007). Peraturan Menteri Negara Pendayagunaan Aparatur Negara Nomor: PER/05/M. Pan, 5, 2007.

Kusharyanti. (2003). Temuan Penelitian Mengenai Kualitas Audit dan Kemungkinan Topik Penelitian di Masa Datang. Akuntansi Dan Manajemen, 25-60.

Pusdiklatwas, B. (2005). Kode Etik dan Standar Audit. Edisi Keempat.

Suraida, I. (2005). Uji Model Etika, Kompetensi, Pengalaman Audit, dan Resiko Audit Terhadap Skeptisme Profesional Auditor. Akuntansi Bandung.

Yamato, M., Okimori, Y., Wibowo, I. F., Anshori, S., \& Ogawa, M. (2006). Effects of the application of charred bark of Acacia mangium on the yield of maize, cowpea and peanut, and soil chemical properties in South Sumatra, Indonesia. Soil Science and Plant Nutrition, 52(4), 489-495. 